\title{
Transactions of the Royal Asiatic Society of Great Britain and Ireland
}

http://journals.cambridge.org/TRA

Additional services for Transactions of the Royal Asiatic Society of Great Britain and Ireland:

Email alerts: $\underline{\text { Click here }}$

Subscriptions: Click here

Commercial reprints: $\underline{\text { Click here }}$

Terms of use : $\underline{\text { Click here }}$

\section{Remarks on the Identity of the Personal Ornaments sculptured on some Figures in the Budd'ha Cave Temples at Carli, with those worn by the Brinjaris}

William Henry Sykes

Transactions of the Royal Asiatic Society of Great Britain and Ireland / Volume 3 / Issue 03 / July 1834, pp 451 451

DOI: 10.1017/S0950473700001178, Published online: 24 September 2009

Link to this article: http://journals.cambridge.org/abstract_S0950473700001178

How to cite this article:

William Henry Sykes (1834). XXVIII. Remarks on the Identity of the Personal Ornaments sculptured on some Figures in the Budd'ha Cave Temples at Carli, with those worn by the Brinjaris. Transactions of the Royal Asiatic Society of Great Britain and Ireland, 3, pp 451-451 doi:10.1017/

S0950473700001178

Request Permissions : $\underline{\text { Click here }}$ 
XXVIII. Remarks on the Identity of the Personal Ornaments sculptured on some Figures in the Budd'ha Cave Temples at Carli, with those worn by the Brinjaris. By Lieut.-Colonel WILLIAM HENRY SYKES, F.L.S., F.G.S., \&c.

Communicated by the BombaY BraNCH of the Royal Asiatic Society.

\section{Read the 17th of March 1832.}

I AM induced to offer to the Society a sketch* of the personal ornaments on the alto-relievo figures, male and female, in the Budd'ha cave temple of Carli, from having remarked an apparent identity in the majority of the sculptured ornaments, with those worn by that remarkable, erratic, carrying and armed, but essentially pastoral people, the Brinjaris; a people whose origin and history admit of further development. My acquaintance with the Brinjaris is too limited to justify me in advancing any opinion on a community of taste between them and the ancient Budd'has, and although such community, if existing in the constitution of European society, would not excite attention, it will be considered, at least, curious in India, where the classes of society are not less marked by caste than by habits of life, opinions, dress, and personal ornaments.

Should the identity I have noticed, open to any future inquirer into the origin and history of the Brinjaris, a new channel for the prosecution of his labours, my object in laying this sketch before the Society will be fulfilled.

I have used the term "carrying," in speaking of the Brinjaris, in allusion to their practice of employing their bullocks in thousands, to transport grain, salt, \&c. over the country. When not occupied in their transit labours, these people are found pasturing their cattle on waste lands, and at this period they live principally on the milk of their cows. They always dwell in small tents, consisting of pieces of cloth stretched over horizontal poles supported on two sticks, the walls of the tents being made of bullock packs piled on each other.

(Signed) W. H. Sykes.

VoL. III.

* See accompanying Plate.

$3 \mathrm{~N}$ 